\title{
Increased renal vasodilator prostanoids prevent hypertension in mice lacking the angiotensin subtype-2 receptor
}

\author{
Helmy M. Siragy, ${ }^{1}$ Takaaki Senbonmatsu, ${ }^{2}$ Toshihiro Ichiki, ${ }^{2}$ Tadashi Inagami, ${ }^{2}$ \\ and Robert M. Carey ${ }^{1}$ \\ ${ }^{1}$ Department of Medicine, University of Virginia School of Medicine, Charlottesville, Virginia 22908, USA \\ ${ }^{2}$ Department of Biochemistry, Vanderbilt University School of Medicine, Nashville, Tennessee, 37232, USA \\ Address correspondence and reprint requests to: Robert M. Carey, Box 395, University of Virginia Health Sciences Center, \\ Charlottesville, Virginia 22908, USA. Phone: (804) 924-5510; Fax: (804) 982-3626; E-mail: rmc4c@virginia.edu.
}

Received for publication December 15, 1998, and accepted in revised form June 10, 1999.

\begin{abstract}
The angiotensin subtype-1 $\left(\mathrm{AT}_{1}\right)$ receptor mediates renal prostaglandin $\mathrm{E}_{2}\left(\mathrm{PGE}_{2}\right)$ production, and pharmacological blockade of the angiotensin subtype-2 $\left(\mathrm{AT}_{2}\right)$ receptor potentiates the action of angiotensin II (Ang II) to increase $\mathrm{PGE}_{2}$ levels. We investigated the role of the $\mathrm{AT}_{2}$ receptor in prostaglandin metabolism in mice with targeted deletion of the $\mathrm{AT}_{2}$ receptor gene. Mice lacking the $\mathrm{AT}_{2}$ receptor $\left(\mathrm{AT}_{2}\right.$-null) had normal blood pressure that was slightly elevated compared with that of wild-type (WT) control mice. $\mathrm{AT}_{2}$-null mice had higher renal interstitial fluid (RIF) 6-keto- $\mathrm{PGF}_{1 \alpha}$ (a stable hydrolysis product of prostacyclin $\left[\mathrm{PGI}_{2}\right]$ ) and $\mathrm{PGE}_{2}$ levels than did WT mice, and had similar increases in $\mathrm{PGE}_{2}$ and 6-keto$\mathrm{PGF}_{1 \alpha}$ in response to dietary sodium restriction and Ang II infusion. In contrast, $\mathrm{AT}_{2}$-null mice had lower $\mathrm{PGF}_{2 \alpha}$ levels compared with WT mice during basal conditions and in response to dietary sodium restriction or infusion of Ang II. RIF cAMP was markedly higher in $\mathrm{AT}_{2}$-null mice than in WT mice, both during basal conditions and during sodium restriction or Ang II infusion. AT $_{1}$ receptor blockade with losartan decreased $\mathrm{PGE}_{2}, \mathrm{PGI}_{2}$, and cAMP to levels observed in WT mice. To determine whether increased vasodilator prostanoids prevented hypertension in $\mathrm{AT}_{2}$-null mice, we treated $\mathrm{AT}_{2}$-null and WT mice with indomethacin for 14 days. $\mathrm{PGI}_{2}, \mathrm{PGE}_{2}$, and cAMP were markedly decreased in both WT and $\mathrm{AT}_{2}$-null mice. Blood pressure increased to hypertensive levels in $\mathrm{AT}_{2}$-null mice but was unchanged in WT. These results demonstrate that in the absence of the $\mathrm{AT}_{2}$ receptor, increased vasodilator prostanoids protect against the development of hypertension.
\end{abstract}

J. Clin. Invest. 104:181-188 (1999).

\section{Introduction}

The renin-angiotensin system constitutes a major hormonal cascade regulating fluid and electrolyte balance and blood pressure (BP), the principal effector of which is angiotensin II (Ang II) (1). The vast majority of the physiological effects of Ang II are mediated by the subtype-1 $\left(\mathrm{AT}_{1}\right)$ angiotensin receptor; the function of the subtype-2 $\left(\mathrm{AT}_{2}\right)$ receptor remains to be determined (2). $\mathrm{AT}_{2}$ receptors are present in the kidney and are upregulated by sodium depletion and Ang II $(3,4)$.

Ang II stimulates production of prostacyclin $\left(\mathrm{PGI}_{2}\right)$ and prostaglandin $\mathrm{E}_{2}\left(\mathrm{PGE}_{2}\right)(5)$. The angiotensin receptor subtype mediating renal prostanoid formation is largely unknown. We have shown previously in the rat kidney that the $\mathrm{AT}_{1}$ receptor mediates Ang II-induced $\mathrm{PGE}_{2}$ production and that pharmacological blockade of the $\mathrm{AT}_{2}$ receptor potentiates Ang II-induced $\mathrm{PGE}_{2}$ levels (6). We also demonstrated that Ang II stimulates an increase in renal $\mathrm{PGF}_{2 \alpha}$ through an action at the $\mathrm{AT}_{2}$ receptor (7).

This study was conducted to evaluate the role of the $\mathrm{AT}_{2}$ receptor in prostaglandin metabolism and to investigate the mechanisms involving prostaglandins in maintaining normal BP. To address these issues, we used a novel microdialysis technique and mice with targeted disruption of the $\mathrm{AT}_{2}$ receptor gene to monitor changes in 6-keto-PGF ${ }_{1 \alpha}$ (a stable hydrolysis product of $\mathrm{PGI}_{2}$ ), $\mathrm{PGE}_{2}, \mathrm{PGF}_{2 \alpha}$, and cAMP (the major second messenger of $\mathrm{PGE}_{2}$ and $\left.\mathrm{PGI}_{2}\right)$ in renal interstitial fluid (RIF) $(5,8)$.

\section{Methods}

Targeted disruption of the mouse $A T_{2}$ receptor gene. This procedure was performed as described (9). In brief, the coding region of embryonic stem cells (E14-1) in the third exon of the $\mathrm{AT}_{2}$ receptor gene on the $\mathrm{X}$ chromosome was disrupted with a construct containing a neomycin-resistant expression cassette and herpes simplex virus thymidine-kinase expression cassette. The gene-disrupted cells were selected by G418 and ganciclovir, followed by Southern blot analysis to validate the desired gene disruption. Four targeted clones were obtained from 800 double-resistant colonies, 2 of which were injected into blastocysts derived from C57BL/ 6 mice, and the blastocysts were implanted into the uterus of pseudopregnant JCR mice. Of 34 chimeras, germ-line transmission occurred in 11 mice. Heterozygous female mice and wildtype (WT) male mice were mated to generate hemizygous male mice. Homozygous female mice were generated by mating heterozygous females with hemizygous males. The presence of a homozygous mutated $\mathrm{AT}_{2}$ receptor 
gene was confirmed by Southern blot analysis.

Homozygous female $\mathrm{AT}_{2}$-null mice (agtr2 $\left.2^{-/}\right)$and their WT counterparts $\left(\right.$ agtr $\left.2^{+/+}\right)$were generated from the littermates produced from the third backcross of heterozygous females (agtr $\left.2^{+/-}\right)$to C57BL/6 males $\left(\right.$agtr $2^{+/ Y}$ ), as follows. Heterozygous females $\left(\right.$ agtr $\left.2^{+/-}\right)$and hemizygous males $\left(a g t r 2^{-/ Y}\right)$ were crossed to obtain homozygous females (agtr $\left.2^{-/}\right)$. From the same littermates, heterozygous females $\left(\operatorname{agtr} 2^{+/}\right)$and WT males $\left(\operatorname{agtr} 2^{+/ Y}\right)$ were crossed to obtain WT females $\left(\operatorname{agtr} 2^{+/+}\right)$. Mice with the agtr $2^{-/}$genotype were used as $\mathrm{AT}_{2}$-null mice. Those with the agtr $2^{+/+}$genotypes were used as WT. The genotype of each individual mouse was confirmed by Southern blotting of DNA from the tail, as described (9).

Our $\mathrm{AT}_{2}$-null mice were at the third backcross stage, which did not warrant the use of inbred C57BL/6 females as control. Therefore, we produced female agtr $2^{+/+}$and agtr-/- mice by mating littermates produced from the third backcross.

In vivo microdialysis technique. For the determination of RIF autacoids, we constructed a microdialysis probe using a modification of a technique described previously $(6,7,10)$. Substances with a molecular mass greater than $10 \mathrm{kDa}$ cannot cross into the dialysis probe. This molecular mass cutoff allows free passage of 6-keto-PGF $1 \alpha, \mathrm{PGE}_{2}, \mathrm{PGF}_{2 \alpha}$, and cAMP. The dead volume of the dialysis tubing and outflow tube was $3.6 \mu \mathrm{L}$. The microdialysis probe was sterilized by a gas sterilization method. The rate of flow of dialysate was maintained at $3 \mu \mathrm{L} / \mathrm{min}$.

In vitro microdialysis. RIF prostaglandin levels generally parallel, but are more sensitive than, urine prostaglandin excretion. In vitro best recoveries for renal autacoids were observed with a perfusion rate of 3 $\mu \mathrm{L} / \mathrm{min}$, and were $81 \%$ for 6 -keto-PGF $1 \alpha, 63 \%$ for $\mathrm{PGE}_{2}$, $60 \%$ for $\mathrm{PGF}_{2 \alpha}$, and $84 \%$ for cAMP. We have demonstrated previously that negligible amounts of these substances stick to the polyethylene tubes (6).

Animal preparation. Experiments were conducted in 25 homozygous and $25 \mathrm{WT}$ mice 12-16 weeks old. Mice were anesthetized with $80 \mathrm{mg} / \mathrm{kg}$ ketamine (Fort Dodge Laboratories, Fort Dodge, Iowa, USA) and 8 $\mathrm{mg} / \mathrm{kg}$ xylazine (Bayer Corp., Animal Health Division, Shawnee, Kansas, USA), both administered intramuscularly. The right and left kidneys were exposed by a midline abdominal incision. Microdialysis probes were inserted into the kidneys of both the homozygous and WT mice. The renal capsule was penetrated with a 31gauge needle that was tunneled into the outer renal cortex about $1 \mathrm{~mm}$ from the outer renal surface for 0.3 $\mathrm{cm}$ before it exited by penetrating the capsule again. The tip of the needle was inserted into the end of the dialysis probe, and the needle was pulled through with the dialysis tube until the dialysis fiber was situated in the renal cortex. The inflow and outflow tubes of the dialysis probes were tunneled subcutaneously through a bevel-tipped stainless steel tube and exteriorized near the intrascapular region. The exterior ends of the tubes were secured in place by suturing them to the skin at the exit site. The exteriorized portions of the tubes were placed in a stainless steel spring (to prevent the mice from damaging them).
To infuse Ang II or vehicle, an osmotic minipump (model 1007D; Alza Corp., Palo Alto, California, USA) was implanted in the subcutaneous space in the interscapular area, and Ang II or vehicle was infused subcutaneously. No tissue necrosis was observed with Ang II infusion.

Mice were housed under controlled conditions (temperature $21 \pm 1^{\circ} \mathrm{C}$, humidity $60 \pm 10 \%$, lighting for $8-20$ hours). Experiments were initiated at the same time each day to avoid diurnal variation of the measured body weight, systolic blood pressure (SBP), or RIF mediators. For collection of RIF, the inflow tube was connected to a gas-tight syringe that was filled with lactated Ringer's solution and perfused at $3 \mu \mathrm{L} / \mathrm{min}$. The effluent was collected from the outflow tube for 30-minute sample periods in nonheparinized plastic tubes and stored at $-80^{\circ} \mathrm{C}$ until measured for $\mathrm{PGE}_{2}, \mathrm{PGF}_{2 \alpha}$, and cAMP. The known $\mathrm{PGI}_{2^{-}}$and cAMP-generating and -degrading enzymes $(\mathrm{mol} \mathrm{wt}=34,000-150,000)$ do not cross the dialysis membrane because of their size. A histological examination of the renal tissue 6 weeks after insertion of the dialysis probe did not show any fibrosis or scarring (6).

Urine was collected in special metabolic cages designed for individual mice. Urine was collected by a closed system that prevents evaporation or fecal contamination.

$B P$ measurements. SBP was measured in the tail artery in homozygous and WT mice under restraint using an automated sphygmomanometer (model 679; IITC/Life Sciences Instruments, Woodland, California, USA) after a 7-day training period. BPs were recorded at 10minute intervals for 30 minutes each morning during the study period (model 179 Apollo Recorder; Life Sciences Instruments), and values were averaged each day.

Analytical methods. Urinary sodium concentrations were measured with a Nova analyzer (Nova Biomedical, Waltham, Massachusetts, USA). $\mathrm{PGE}_{2}, \mathrm{PGF}_{2 \alpha}$, and 6keto-PGF $1 \alpha$ were measured by an enzymatic immunoassay (Cayman Chemical, Ann Arbor, Michigan, USA). The sensitivities and specificities of the assay for $\mathrm{PGE}_{2}$ were $114 \mathrm{pg} / \mathrm{mL}$ and $100 \%$, respectively; for $\mathrm{PGF}_{2 \alpha}, 14.2$ $\mathrm{pg} / \mathrm{mL}$ and $100 \%$, respectively; and for 6-keto-PGF $1 \alpha, 11$ $\mathrm{pg} / \mathrm{mL}$ and $100 \%$, respectively. The intra- and interassay coefficients of variation were less than $10 \%$ for each assay. cAMP was measured by enzyme immunoassay (Cayman Chemical) with an assay sensitivity of $20 \mathrm{fmol}$ and specificity of $100 \%$.

Effects of dietary sodium restriction on BP, sodium excretion, and RIF mediators. Homozygous $(n=10)$ and WT $(n=10)$ mice were placed in metabolic cages. Baseline BPs and heart rates were measured, and a baseline 24-hour urine collection was obtained for calculation of urine flow rate $(\mathrm{V})$ and sodium excretion $\left(\mathrm{U}_{\mathrm{Na}} \mathrm{V}\right)$. RIF samples were obtained for $\mathrm{PGE}_{2}, \mathrm{PGF}_{2 \alpha}, 6$-keto-PGF $1 \alpha$, and cAMP (experimental day 1) while mice were consuming a normal sodium diet $(0.28 \% \mathrm{NaCl}$; BioServe Biotechnologies Inc., Frenchtown, New Jersey, USA). After experimental day 1 , mice were placed on a low-sodium diet $(0.04 \%$ $\mathrm{NaCl}$ ) for 7 days. On the seventh day of low sodium intake, the study was repeated as already outlined here.

Effects of chronic Ang II infusion on BP, sodium excretion, and RIF autacoids. Homozygous $(n=10)$ and WT $(n=10)$ mice were placed in metabolic cages on normal sodium intake for 10 days. On experimental day 1, a baseline 
$\mathrm{BP}$ and urinary volume and sodium excretion in $\mathrm{AT}_{2}$-null and WT mice

\begin{tabular}{|c|c|c|c|c|c|c|}
\hline & \multicolumn{3}{|c|}{ Wild-type } & \multicolumn{3}{|c|}{$\mathrm{AT}_{2}$-null } \\
\hline & Control & Sodium restriction & Ang II infusion & Control & Sodium restriction & ANG II infusion \\
\hline $\begin{array}{l}\text { Blood pressure } \\
(\mathrm{mmHg})\end{array}$ & $104.8 \pm 0.54$ & $108.5 \pm 1.8$ & $107.1 \pm 0.13$ & $116.6^{A} \pm 0.54$ & $115.2 \pm 0.8$ & $196.6^{\mathrm{B}} \pm 1.2$ \\
\hline $\begin{array}{l}\text { Urine volume } \\
(\mathrm{mL} / 24 \mathrm{~h})\end{array}$ & $1.4 \pm 0.01$ & $1.471 \pm 0.23$ & $1.19 \pm 0.002$ & $2.2 \pm 0.05$ & $2.3 \pm 0.05$ & $0.49^{B} \pm 0.01$ \\
\hline $\begin{array}{l}\text { Urinary sodium excretion } \\
(\mathrm{mEq} / 24 \mathrm{~h})\end{array}$ & $0.28 \pm 0.02$ & $0.02^{C} \pm 0.045$ & $0.25 \pm 0.01$ & $0.6 \pm 0.015$ & $0.05^{\mathrm{B}} \pm 0.002$ & $0.07^{C} \pm 0.003$ \\
\hline
\end{tabular}

$\mathrm{A}=P<0.001$ from $\mathrm{WT} .{ }^{\mathrm{B} P}<0.0002$ from control. ${ }^{C} P<0.0001$ from control.

24-hour urine collection was obtained for calculation of $\mathrm{V}$ and $\mathrm{U}_{\mathrm{Na}} \mathrm{V}$, and RIF samples for $\mathrm{PGE}_{2}, \mathrm{PGF}_{2 \alpha}, 6$ keto-PGF $1 \alpha$, and cAMP were obtained. At 0800 hours on study experimental day 2 , a subcutaneous infusion of Ang II ( $4 \mathrm{pmol} / \mathrm{kg} / \mathrm{min})$ or vehicle was initiated and continued for 6 days (experimental days 2-7) using the osmotic minipump. BP, heart rate, $\mathrm{V}$, and $\mathrm{U}_{\mathrm{Na}} \mathrm{V}$ were monitored daily. On experimental day 7, RIF samples for autacoids were again obtained. At 0800 hours on experimental day 8, the infusion of Ang II was discontinued, and a vehicle infusion was substituted for 4 additional days (experimental days 8-11) while BP, HR, $\mathrm{V}$, and $\mathrm{U}_{\mathrm{Na}} \mathrm{V}$ measurements were continued.

Effects of indomethacin on BP, sodium excretion, and RIF mediators. To determine whether the absence of a large rise in baseline $\mathrm{BP}$ in $\mathrm{AT}_{2}$-null mice was due to an increase in renal $\mathrm{PGE}_{2}$, we administered indomethacin, a cyclooxygenase inhibitor, to homozygous $(n=10)$ and WT $(n=10)$ mice during normal sodium intake. After baseline RIF measurements on control day 0 , as already described here, mice were given indomethacin (5 $\mathrm{mg} / \mathrm{kg} / \mathrm{d}$ ) or vehicle intraperitoneally for 14 experimental days. BP was measured daily. At the end of this time, the measurements were repeated. No gastrointestinal toxicity due to indomethacin was observed.

Effects of $A T_{1}$ receptor blockade on RIF autacoids in $A T_{2^{-}}$ null mice. To determine the mechanism of the increase in renal $\mathrm{PGE}_{2}, 6$-keto-PGF ${ }_{1 \alpha}$, and $\mathrm{cAMP}$ in $\mathrm{AT}_{2}$-null mice, we administered a bolus dose of $10 \mathrm{mg} / \mathrm{kg}$ of the $\mathrm{AT}_{1}$ receptor antagonist losartan via tail vein to conscious $\mathrm{AT}_{2}$-null mice $(n=5)$ with an indwelling renal microdialysis probe. Two hours later, RIF was obtained over a 1-hour collection period for $\mathrm{PGE}_{2}, 6$ keto-PGF $1 \alpha$, and cAMP.

Effects of $\mathrm{AT}_{2}$ receptor blockade on RIF autacoids in WT. To confirm the mechanism of the reduction in $\mathrm{PGF}_{2 \alpha}$ in $\mathrm{AT}_{2}$-null mice, we administered the $\mathrm{AT}_{2}$ receptor antagonist PD123319 (PD; $50 \mu \mathrm{g} / \mathrm{kg} / \mathrm{min})$ to WT mice $(n=5)$ by osmotic minipump for 5 consecutive days. RIF samples were collected on day 1 after initiation of a vehicle infusion or infusion of PD with the animals on a normal sodium diet $(0.31 \%$ sodium $)$, after which they were placed on a low-sodium diet ( $0.08 \%$ sodium) for 4 days during vehicle or $\mathrm{PD}$ infusion. RIF $\mathrm{PGE}_{2}$ and $\mathrm{PGF}_{2 \alpha}$ were again measured on day 5 of the low-sodium diet in the presence of PD or vehicle.

Statistical analysis. Comparisons between normal and low sodium intake, and between Ang II or indomethacin and vehicle, were estimated by repeatedmeasures ANOVA, using the General Linear Models procedure of the Statistical Analysis System (Virginia Polytechnic and State University, Blacksburg, Virginia, USA). Multiple comparisons of individual pairs of effect means were conducted by least-square means pooled variance. Data are expressed as mean \pm SEM. Statistical significance was identified at $P<0.05$.

\section{Results}

$B P, V$, and $U_{N a} V$ responses to dietary sodium restriction and $A n g$ II infusion. BP was slightly but significantly higher in $\mathrm{AT}_{2^{-}}$ null mice $(n=10)$ than in WT mice $(n=10)$ at baseline (Table 1). Sodium restriction did not alter BP in either $\mathrm{AT}_{2}$-null or WT mice. Ang II infusion increased BP significantly in $\mathrm{AT}_{2}$-null mice but not in WT mice. $\mathrm{V}$ and $\mathrm{U}_{\mathrm{Na}} \mathrm{V}$ were similar in $\mathrm{AT}_{2}$-null and WT mice. In response to sodium restriction, $V$ was unchanged but $\mathrm{U}_{\mathrm{Na}} \mathrm{V}$ was significantly reduced in both $\mathrm{WT}$ and $\mathrm{AT}_{2}$-null mice. Ang II infusion decreased $\mathrm{V}$ and $\mathrm{U}_{\mathrm{Na}} \mathrm{V}$ significantly in $\mathrm{AT}_{2}$-null mice but not in WT mice.

RIF $P G E_{2}, P G F_{20}$, 6-keto-PGF $F_{10}$ and cAMP responses to dietary sodium restriction. Figure $1 \mathrm{a}$ depicts $\mathrm{PGE}_{2}$ levels during normal sodium intake and after 7 days of dietary sodium restriction. During normal sodium intake, $\mathrm{PGE}_{2}$ was significantly increased in $\mathrm{AT}_{2}$-null mice compared with WT mice. Dietary sodium restriction increased $\mathrm{PGE}_{2}$ both in $\mathrm{AT}_{2}$-null and WT mice. In sodium-restricted animals, $\mathrm{PGE}_{2}$ levels in $\mathrm{AT}_{2}$-null mice were more than 2-fold higher than in WT mice. Figure $1 \mathrm{~b}$ demonstrates $\mathrm{PGF}_{2 \alpha}$ levels. $\mathrm{PGF}_{2 \alpha}$ was significantly lower in $\mathrm{AT}_{2}$-null mice than in WT mice during normal sodium intake. Dietary sodium restriction increased $\mathrm{PGF}_{2 \alpha}$ in WT mice but significantly decreased $\mathrm{PGF}_{2 \alpha}$ in $\mathrm{AT}_{2}$-null mice. In sodiumrestricted animals, $\mathrm{PGF}_{2 \alpha}$ levels were more than 10 -fold higher in WT mice than in $\mathrm{AT}_{2}$-null mice. Figure $1 \mathrm{c}$ shows RIF levels of 6-keto-PGF $1 \alpha$. Basal levels of 6-keto$\mathrm{PGF}_{1 \alpha}$ were higher in $\mathrm{AT}_{2}$-null mice than in $\mathrm{WT}$ mice. In both WT and $\mathrm{AT}_{2}$-null mice, 6-keto-PGF $1 \alpha$ increased significantly in response to sodium restriction. There was no significant difference in the incremental change to sodium restriction between $\mathrm{WT}$ and $\mathrm{AT}_{2}$-null mice. $\mathrm{AT}_{2}$-null mice had approximately 26-fold higher cAMP levels (Figure 1d) than did WT mice during normal sodium intake. Low sodium intake resulted in no significant change in cAMP in either $\mathrm{AT}_{2}$-null or WT mice.

RIF $P G E_{2}, P G F_{2 \alpha}$, 6-keto- $P G F_{1 \alpha}$, and cAMP responses to chronic Ang II infusion. $\mathrm{AT}_{2}$-null mice had higher $\mathrm{PGE}_{2}$ 
levels (Figure 2a) than did WT mice during vehicle infusion. Ang II infusion increased $\mathrm{PGE}_{2}$ in both WT and $\mathrm{AT}_{2}$-null mice, the increase being significantly greater in WT mice. After Ang II infusion, $\mathrm{AT}_{2}$-null mice had $\mathrm{PGE}_{2}$ levels similar to those in WT mice. $\mathrm{AT}_{2^{-}}$ null mice had lower $\mathrm{PGF}_{2 \alpha}$ levels (Figure $2 \mathrm{~b}$ ) than did WT mice during vehicle infusion. In WT mice, $\mathrm{PGF}_{2 \alpha}$ was increased approximately 4-fold by chronic Ang II infusion, whereas in $\mathrm{AT}_{2}$-null mice, there was no significant change in $\mathrm{PGF}_{2 \alpha}$ levels in response to Ang II. Responses of 6-keto-PGF $1 \alpha$ to exogenous Ang II are shown in Figure 2c. Basal control levels of 6-keto$\mathrm{PGF}_{1 \alpha}$ were higher in $\mathrm{AT}_{2}$-null mice than in $\mathrm{WT}$ mice. Both WT and $\mathrm{AT}_{2}$-null mice had significant increases in 6-keto-PGF $1 \alpha$ in response to Ang II, and there was no difference in these responses between the two. cAMP values (Figure $2 \mathrm{~d}$ ) were significantly higher in $\mathrm{AT}_{2}$-null mice than in WT mice, both basally and in response to Ang II. Ang II did not significantly alter cAMP in either WT or $\mathrm{AT}_{2}$-null mice.

$B P$ responses to indomethacin. In $\mathrm{AT}_{2}$-null mice, $\mathrm{BP}$ increased progressively and dramatically well into the hypertensive range in response to intraperitoneally administered indomethacin $(5 \mathrm{mg} / \mathrm{kg} / \mathrm{d}$ ) (Figure 3 ).
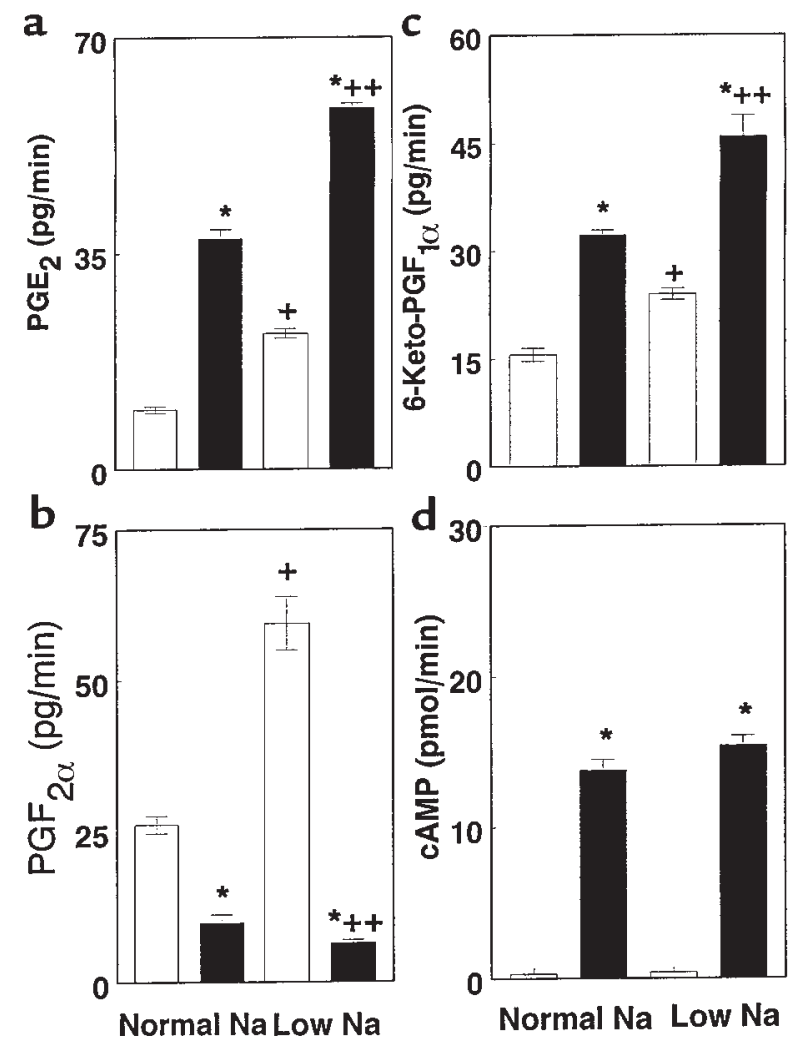

\section{Figure 1}

RIF PGE $2(\mathbf{a}), \mathrm{PGF}_{2 \alpha}(\mathbf{b})$, 6-keto-PGF $1 \alpha(\mathbf{c})$, and cAMP (d) in mice ( $n=10)$ lacking the $\mathrm{AT}_{2}$ angiotensin receptor (filled bars) and in WT mice $(n=10$; open bars), on normal or low dietary sodium $(\mathrm{Na})$ intake. (a) ${ }^{*} P<0.0005$ vs. WT; ${ }^{+} P<0.005,{ }^{++} P<0.001$ vs. normal sodium intake. (b) ${ }^{*} P<0.001$ vs. WT; ${ }^{+} P<0.05,{ }^{++} P<0.001$ vs. normal sodium intake. (c) ${ }^{*} P<0.001$ vs. WT; ${ }^{+} P<0.01,{ }^{++} P<0.001$ vs. normal sodium intake. (d) ${ }^{*} P<0.0005$ vs. WT.
There was no change in BP on any day of the vehicle time control. BP before vehicle administration was $102 \pm 5$ $\mathrm{mmHg}$ and was $103 \pm 2 \mathrm{mmHg}$ after 14 days of vehicle administration. There was no change in BP in WT mice in response to indomethacin (Figure 3 ).

RIF $P G E_{2}, P G F_{2 \alpha}$ and $c A M P$ responses to chronic indomethacin administration. $\mathrm{PGE}_{2}$ (Figure $4 \mathrm{a}$ ) values were about 3.5-fold higher in $\mathrm{AT}_{2}$-null mice than in WT mice on day 0 before indomethacin administration. In response to 14 consecutive days of indomethacin administration, $\mathrm{PGE}_{2}$ was significantly decreased in both WT and $\mathrm{AT}_{2}$-null mice. $\mathrm{PGE}_{2}$ values were not significantly different in WT and $\mathrm{AT}_{2}$-null mice after 14 days of indomethacin administration. $\mathrm{PGF}_{2 \alpha}$ levels (Figure 4b) were more than 3 -fold lower in $\mathrm{AT}_{2}$-null mice than in WT mice at baseline. Indomethacin lowered $\mathrm{PGF}_{2 \alpha}$ both in WT and $\mathrm{AT}_{2}$-null mice. In indomethacin-treated animals, $\mathrm{PGF}_{2 \alpha}$ was significantly lower in $\mathrm{AT}_{2}$-null mice than in WT mice. Indomethacin decreased 6-keto-PGF ${ }_{1 \alpha}$ levels significantly in both WT and $\mathrm{AT}_{2}$-null mice, such that levels were not significantly different between the two (Figure 4c). cAMP levels (Figure 4d) in WT mice were low and were unchanged by indomethacin. In $\mathrm{AT}_{2}$-null mice, cAMP levels were relatively high at baseline and were markedly reduced.

RIF $P G E_{2}, 6-k e t o-P G F_{10}$ and cAMP responses to $A T_{1}$ receptor blockade in $A T_{2}$-null mice. As shown in Figure 5, control values for $\mathrm{PGE}_{2}$, 6-keto-PGF $1 \alpha$, and cAMP in $\mathrm{AT}_{2}$-null mice were $39 \pm 7,39 \pm 4$, and $16 \pm 3 \mathrm{pg} / \mathrm{min}$, respectively. In response to losartan, $\mathrm{PGE}_{2}$ decreased $(P<0.0001)$ to less than one third of control values and to a value similar to that of WT mice. Similarly, 6-keto-PGF $F_{1 \alpha}$ decreased to about $40 \%$ of control values $(P<0.0001)$. Losartan caused a parallel reduction of cAMP $(P<$ $0.0001)$ to values similar to those of WT mice.

RIF $P G E_{2}$ and $P G F_{2 \alpha}$ responses to $A T_{2}$ receptor blockade in sodium-restricted WT mice. Figure 6 depicts the incremental increase in $\mathrm{PGE}_{2}$ and $\mathrm{PGF}_{2 \alpha}$ in response to dietary sodium restriction for 5 days in the presence or absence of continuous intravenous infusion of PD. Sodium restriction increased both $\mathrm{PGE}_{2}$ and $\mathrm{PGF}_{2 \alpha}$ in mice receiving only vehicle infusion. $\mathrm{AT}_{2}$ receptor blockade with PD further increased $\mathrm{PGE}_{2}$ but decreased the $\mathrm{PGF}_{2 \alpha}$ response to sodium restriction (both $P<0.01$ ).

\section{Discussion}

This study demonstrates that Ang II acts at the $\mathrm{AT}_{1}$ receptor to stimulate both $\mathrm{PGI}_{2}$ and $\mathrm{PGE}_{2}$ production in the kidney. $\mathrm{PGE}_{2}$ is the major renal prostanoid and has substantially greater vasodilator potency than $\mathrm{PGI}_{2}$ in the rat kidney (5). $\mathrm{PGI}_{2}$ is the major metabolite of arachidonic acid in vascular endothelial cells (6). The baseline increase in renal $\mathrm{PGE}_{2}$ and 6-keto-PGF $\mathrm{PG}_{1 \alpha}$ in $\mathrm{AT}_{2}$-null mice is the result of interruption of receptor cross-talk and the presence of "unopposed" $\mathrm{AT}_{1}$ receptors in these mice, as $\mathrm{AT}_{1}$ receptor blockade normalized $\mathrm{PGE}_{2}$ and 6-keto-PGF $1 \alpha$ in $\mathrm{AT}_{2}$-null mice. These observations suggest that the $\mathrm{AT}_{2}$ receptor has a tonic inhibitory action on the production of $\mathrm{PGI}_{2}$ and $\mathrm{PGE}_{2}$, which is driven by the $\mathrm{AT}_{1}$ receptor.

It is generally appreciated that Ang II can stimulate $\mathrm{PGI}_{2}$ and $\mathrm{PGE}_{2}$ production in nonrenal tissues. Studies 
using isolated vascular smooth muscle cells and isolated perfused heart preparations have demonstrated that Ang II stimulates $\mathrm{PGI}_{2}$ release through an interaction at $\mathrm{AT}_{1}$ receptors (11-15). However, the angiotensin subtype receptor responsible for renal $\mathrm{PGE}_{2}$ and $\mathrm{PGI}_{2}$ formation has not been studied systematically. The results of the present study show that both renal $\mathrm{PGI}_{2}$ and $\mathrm{PGE}_{2}$ production are stimulated in parallel by either endogenous (sodium restriction) or exogenous Ang II.

$\mathrm{PGI}_{2}$ and $\mathrm{PGE}_{2}$ are both formed from the precursor $\mathrm{PGH}_{2}$, which is a product of cyclooxygenase action on its substrate, arachidonic acid. $\mathrm{PGF}_{2 \alpha}$, another major renal prostanoid, can also be formed directly from $\mathrm{PGH}_{2}$ or, alternatively, by conversion from $\mathrm{PGE}_{2}$ through the action of $\mathrm{PGE}_{2}$ 9-ketoreductase (5). Prostaglandins are paracrine or autocrine substances, acting locally in the tissues in which they are formed (5). Because of their rapid degradation on passage across the lungs, these substances are not detectable in appreciable quantities in the circulation. However, prostanoids can be assayed and changes monitored in RIF with a high degree of sensitivity (6). $\mathrm{PGE}_{2}$ and $\mathrm{PGF}_{2 \alpha}$ are produced in renal interstitial and collecting duct cells and in the endothelium of vasa recta, and they participate in the regulation of renal function (16, 17). The production of these autacoids is augmented by pressor hormones, including Ang II via stimulation of phospholipase $A_{2}$, to form arachidonic acid substrate from membrane phospholipids $(5,18)$. Ang II stimulates the endothelial release of arachidonic acid metabolites (19-21). We have shown previously in the rat that Ang II stimulates renal $\mathrm{PGE}_{2}$ production through the $\mathrm{AT}_{1}$ receptor (6). Our present results are consistent with earlier observations in the normal rat kidney that conversion of $\mathrm{PGE}_{2}$ to $\mathrm{PGF}_{2 \alpha}$ by 9-ketoreductase is enhanced by sodium depletion $(22,23)$.

An important finding of the present study is that Ang II acts at the $\mathrm{AT}_{2}$ receptor to stimulate $\mathrm{PGF}_{2}$, probably by conversion from $\mathrm{PGE}_{2}$. At baseline, mice lacking the $\mathrm{AT}_{2}$ receptor had increased $\mathrm{RIF}$ levels of $\mathrm{PGE}_{2}$ and low levels of $\mathrm{PGF}_{2 \alpha}$. In WT mice, both sodium restriction (endogenous Ang II) and chronic infusion of a small quantity of exogenous Ang II increased 6-keto-PGF $1 \alpha$, $\mathrm{PGE}_{2}$, and $\mathrm{PGF}_{2 \alpha}$. Similarly, in $\mathrm{AT}_{2}$-null mice, sodium restriction and chronic Ang II infusion increased 6keto-PGF $1 \alpha$ and $\mathrm{PGE}_{2}$. In marked contrast to WT mice, however, in $\mathrm{AT}_{2}$-null mice, both exogenous and endogenous Ang II failed to increase $\mathrm{PGF}_{2 \alpha}$. These results were

Figure 3

SBP of mice $(n=10)$ lacking the $\mathrm{AT}_{2}$ angiotensin receptor (triangles) and of WT mice ( $n=10$, circles) during vehicle infusion (day 0 ) and during continuous intraperitoneal infusion of indomethacin $(5 \mathrm{mg} / \mathrm{kg} / \mathrm{d})$ for 14 days. ${ }^{*} P<0.001$ vs. day 0 and WT. ${ }^{+} P<0.0001$ vs. day 0 and WT.
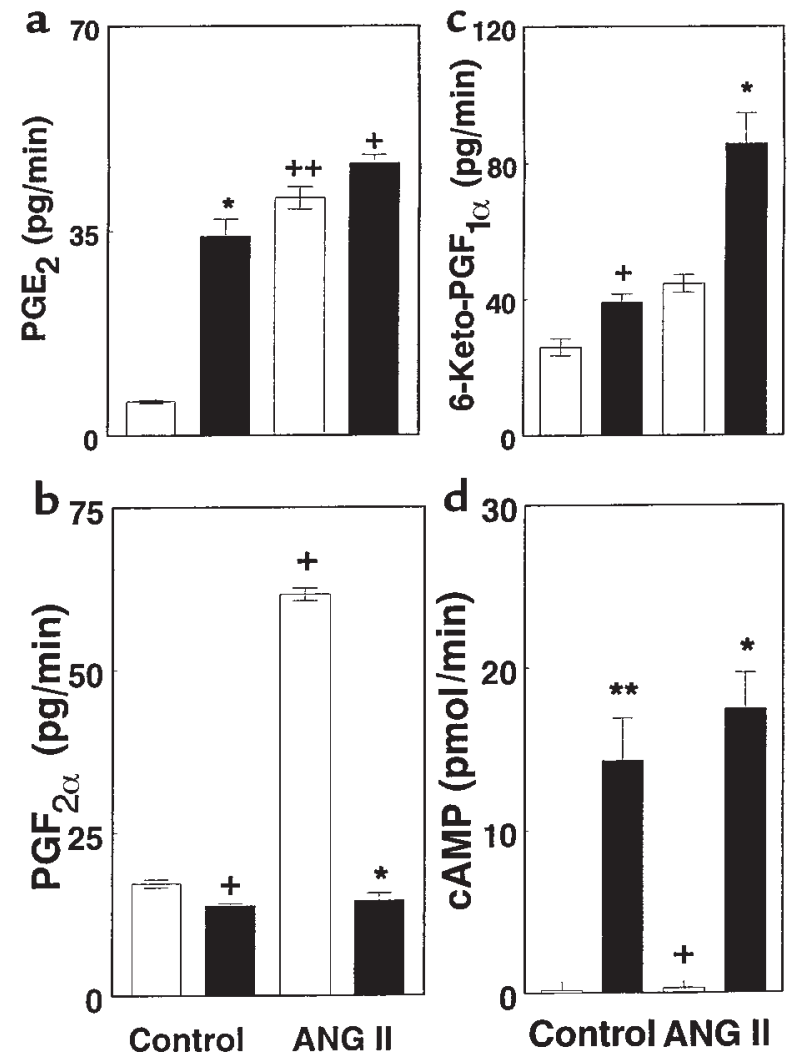

Figure 2

RIF PGE $2(\mathbf{a}), \mathrm{PGF}_{2 \alpha}(\mathbf{b}), 6$-keto-PGF $1 \alpha(\mathbf{c})$, and cAMP $(\mathbf{d})$ in mice $(n=10)$ lacking the $\mathrm{AT}_{2}$ angiotensin receptor (filled bars) and in WT mice ( $n=10$; open bars) during the vehicle control period (Control) and after 7 days of continuous infusion of Ang II. (a) ${ }^{*} P<0.01$ vs. WT; ${ }^{+} P<0.05,{ }^{++} P<$ 0.0005 vs. control. (b) ${ }^{*} P<0.001,{ }^{*} P<0.0001$ vs. WT; ${ }^{*} P<0.0001$ vs. control. (c) ${ }^{*} P<0.0005$ vs. WT; ${ }^{+} P<0.05$ vs. control. (d) ${ }^{*} P<0.01,{ }^{*} P$ $<0.001$ vs. WT; ${ }^{+} P<0.002$ vs. control.

confirmed by experiments showing that sodium restriction increased $\mathrm{PGE}_{2}, \mathrm{PGI}_{2}$, and $\mathrm{PGF}_{2 \alpha}$, and by separate experiments showing that $\mathrm{AT}_{2}$ receptor blockade with $\mathrm{PD}$ blocked the increase in $\mathrm{PGE}_{2}$ in WT mice. Our results underscore the physiological importance of the $\mathrm{AT}_{2}$ receptor in the formation of $\mathrm{PGF}_{2 \alpha}$, most likely through conversion from $\mathrm{PGE}_{2}$ by 9-ketoreductase. Our data, however, do not permit determination of the effects, if any, of the $\mathrm{AT}_{2}$ receptor on $\mathrm{PGH}_{2}$ metabolism. Our data demonstrate that the increase in basal $\mathrm{PGE}_{2}$

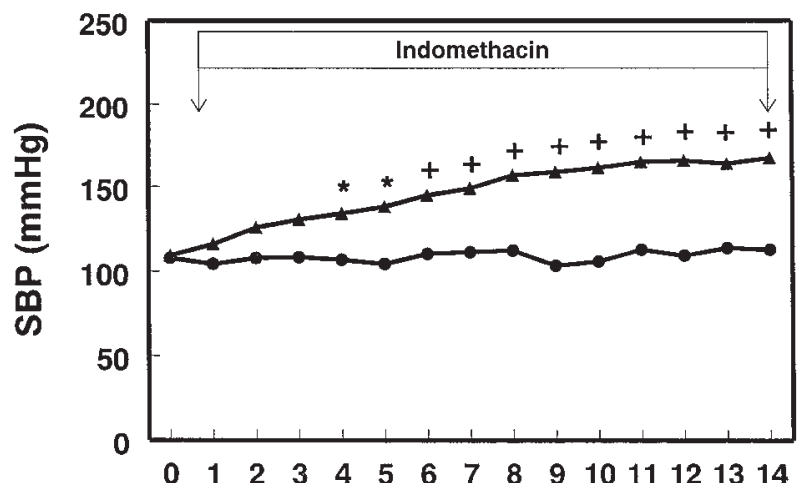




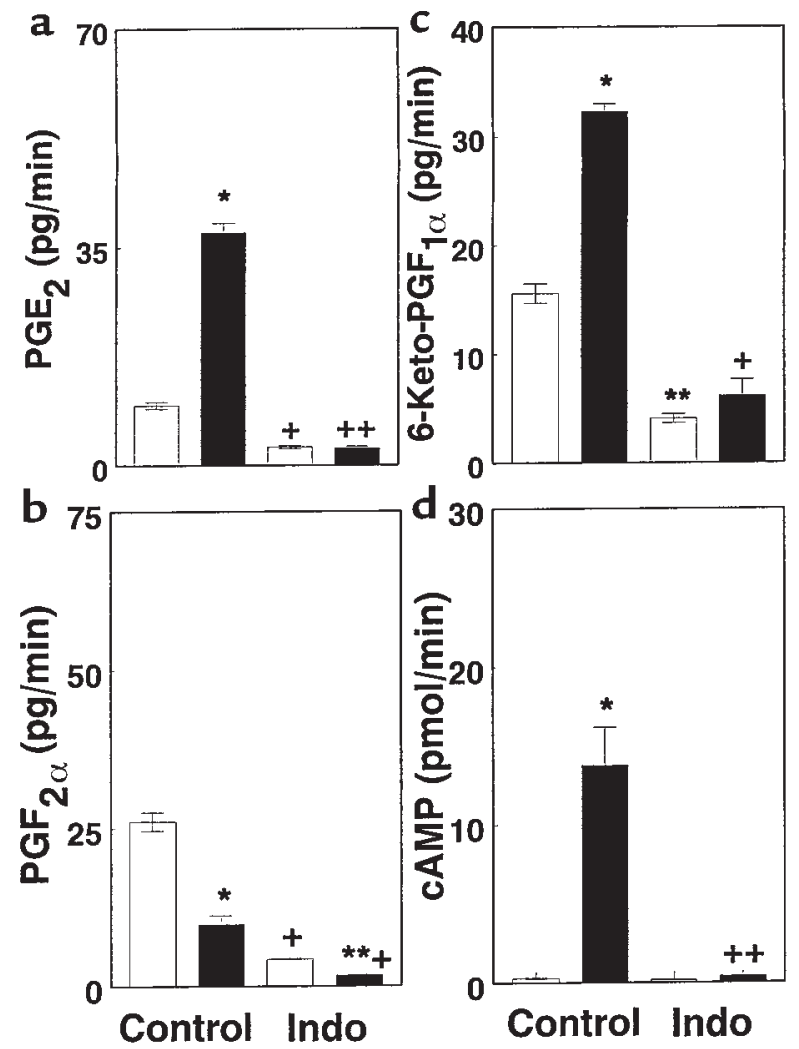

Figure 4

RIF PGE $E_{2}(\mathbf{a}), \operatorname{PGF}_{2 \alpha}(\mathbf{b}), 6-$ keto-PGF $1 \alpha(\mathbf{c})$, and $\operatorname{cAMP}(\mathbf{d})$ in mice $(n=$ 10) lacking the $A T_{2}$ angiotensin receptor (filled bars) and in WT mice $(n=10$; open bars) during the vehicle control period (Control) and after 14 days of indomethacin administration $(5 \mathrm{mg} / \mathrm{kg} / \mathrm{d}$ intraperitoneally). (a) ${ }^{*} P<0.0005$ vs. WT; ${ }^{+} P<0.005,{ }^{++} P<0.0005$ vs. control. (b) ${ }^{*} P<0.001,{ }^{*} P<0.0001$ vs. WT; ${ }^{+} P<0.0001$ vs. control. (c) ${ }^{*} P<$ 0.001 vs. WT; ${ }^{+} P<0.0001,{ }^{*} P<0.0001$ vs. control. (d) ${ }^{*} P<0.001$ vs. WT. ${ }^{++} P<0.0005$ vs. control.

in $\mathrm{AT}_{2}$-null mice is largely related to absence of tonic inhibition of the $\mathrm{AT}_{2}$ receptor on $\mathrm{AT}_{1}$ receptor-mediated $\mathrm{PGE}_{2}$ production.

The interaction between the renin-angiotensin system and renal eicosanoids is fundamental to the regulation of body fluid and sodium homeostasis (8). $\mathrm{PGI}_{2}$ and $\mathrm{PGE}_{2}$ stimulate, whereas $\mathrm{PGF}_{2 \alpha}$ inhibits, renin secretion (24). $\mathrm{AT}_{2}$ receptor-mediated stimulation of $\mathrm{PGF}_{2 \alpha}$ formation, and its inhibitory effect on renin secretion, is in agreement with recent findings that the $\mathrm{AT}_{2}$ receptor may indirectly mediate vasodilation (9). $\mathrm{PGE}_{2}$ inhibits sodium reabsorption in the cortical and medullary collecting ducts and leads to natriuresis (25). Sodium depletion increases renal Ang II formation (26), and it is likely that the resulting increase in conversion of $\mathrm{PGE}_{2}$ to $\mathrm{PGF}_{2 \alpha}$ is related to increased Ang II formation and stimulation of the $\mathrm{AT}_{2}$ receptor. The decrease in sodium excretion during sodium restriction is likely mediated by $\mathrm{AT}_{1}$ receptors in renal tubule cells in both WT and $\mathrm{AT}_{2}$-null mice.

The tonic inhibitory action of the $\mathrm{AT}_{2}$ receptor on $A T_{1}$ receptor-mediated $\mathrm{PGI}_{2}$ and $\mathrm{PGE}_{2}$ production may be due to several possible factors. (a) Nitric oxide, which is increased by $\mathrm{AT}_{2}$ receptors, has been described to inhibit cyclooxygenase under some conditions (27, 28). (b) cGMP, also increased by $\mathrm{AT}_{2}$ receptors, may affect prostaglandin metabolism (28). (c) Bradykinin, also increased by $\mathrm{AT}_{2}$ receptors, can stimulate the production of nitric oxide and eicosanoids in the intact kidney (29). (d) The $\mathrm{AT}_{2}$ receptor may stimulate epoxide production through the cytochrome $\mathrm{P}_{450}$ system, which may compete with arachidonic acid for metabolism by cyclooxygenase, resulting in inhibition of $\mathrm{PGI}_{2}$ and $\mathrm{PGE}_{2}$ formation $(30,31)$. These possibilities will need to be resolved in future studies.

$\mathrm{PGF}_{2 \alpha}$, the product of $\mathrm{PGE}_{2}$ metabolism by 9-ketoreductase, binds mainly to the recently cloned FP receptor, resulting in a rise in intracellular calcium (32). The FP receptor is thought to mediate vasoconstriction. $\mathrm{PGF}_{2 \alpha}$ also can bind to $\mathrm{EP}_{1}$ and $\mathrm{EP}_{3}$ receptors, both of which also mediate vasoconstriction (32). In $\mathrm{AT}_{2}$-null mice, the decrease in $\mathrm{PGF}_{2 \alpha}$ may contribute to the absence of hypertension by reducing peripheral and/or renal vasoconstriction.

$\mathrm{PGE}_{2}$ has been shown to stimulate adenylyl cyclase via the $\mathrm{EP}_{2}$ and $\mathrm{EP}_{4}$ receptors with the generation of cAMP, which acts as its second messenger $(8,32)$. These 2 receptors mediate vascular smooth muscle relaxation. cAMP is extruded from target cells by a prostanoid-sensitive membrane transporter and can be measured in the RIF. Our data demonstrate that cAMP levels were high in $\mathrm{AT}_{2}$-null mice ( $\mathrm{PGE}_{2}$ and $\mathrm{PGI}_{2}$ levels also were elevated) compared with WT mice. An unanticipated finding was the failure of cAMP to increase in WT mice in response to sodium restriction or Ang II in proportion to the increase in $\mathrm{PGE}_{2}$. The parallel reduction of $\mathrm{PGE}_{2}, 6$-keto$\mathrm{PGF}_{1 \alpha}$, and cAMP by indomethacin suggests, however, that $\mathrm{PGE}_{2}$ and/or $\mathrm{PGI}_{2}$ are very likely responsible for elevated cAMP in $\mathrm{AT}_{2}$-null mice. Failure of cAMP to increase substantially in response to sodium restriction or Ang II in $\mathrm{AT}_{2}$-null mice may indicate maximum stimulation of cAMP production in the basal state.

Both $\mathrm{PGE}_{2}$ and $\mathrm{PGI}_{2}$ are vasodilators, and excessive vasodilator prostanoid accumulation in the absence of the $\mathrm{AT}_{2}$ receptor may account for the absence of hypertension in this model. To test this hypothesis, we administered the cyclooxygenase inhibitor indomethacin and monitored BP. In response to indomethacin, which decreased renal 6-keto-PGF $1 \alpha, \mathrm{PGE}_{2}$, and $\mathrm{PGF}_{2 \alpha}$ to low levels, BP steadily rose into the hypertensive range. These results suggest that increased $\mathrm{PGI}_{2}$ and $\mathrm{PGE}_{2}$ in $\mathrm{AT}_{2}$-null mice prevented the increase in BP that otherwise would have occurred, most likely owing to a reduction of other vasodilators such as bradykinin and/or nitric oxide, which are stimulated via the $\mathrm{AT}_{2}$ receptor (6). It is also possible that in addition to decreasing vasodilator prostanoid production, indomethacin may have selectively inhibited vasodilator prostanoid signal transduction in target cells, as has been demonstrated in the cerebral microcirculation (33). Therefore, the action of indomethacin to increase BP could be related to inhibition of both vasodilator prostanoid synthesis and action.

There are several limitations to the present study. (a) We were unable to measure plasma renin activity or Ang II concentrations because volume depletion might have 

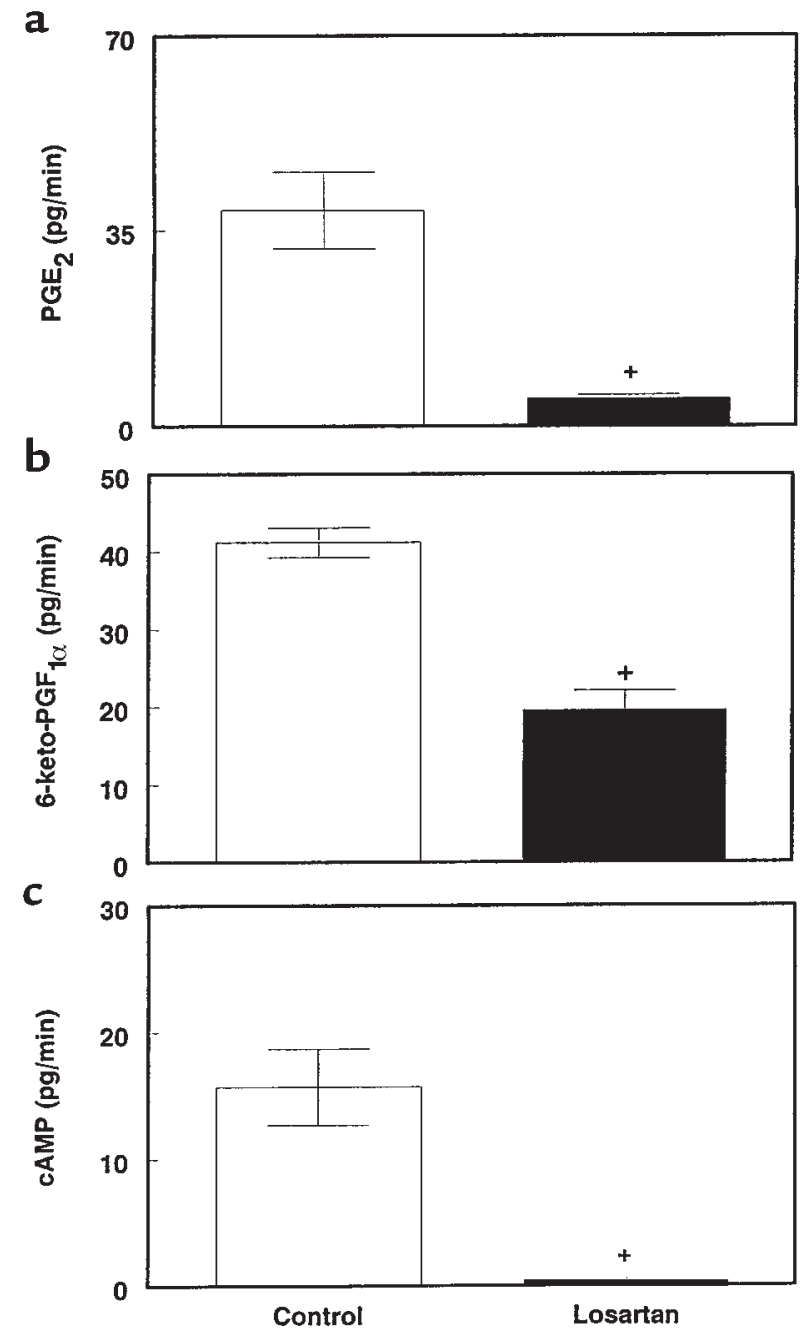

Figure 5

RIF PGE $2(\mathbf{a}), 6$-keto-PGF $1 \alpha(\mathbf{b})$, and cAMP $(\mathbf{c})$ in WT mice $(n=5)$ before and 2 hours after intravenous losartan administration (10 $\mathrm{mg} / \mathrm{kg}) .{ }^{+} P<0.0001$ vs. control.

altered RIF autacoid levels. (b) Although we were able to monitor $\mathrm{PGE}_{2}$ and $\mathrm{PGF}_{2 \alpha}$ levels, we were not able to measure the activity of $\mathrm{PGE}_{2}$ 9-ketoreductase directly. (c) Indomethacin has been reported to inhibit enzyme systems and cell signaling processes other than cyclooxygenase activity, including cAMP- and cGMP-phosphodiesterases, cAMP-dependent protein kinases and endogenous phosphorylation, active $\mathrm{Ca}^{2+}$ transport, and adenosine uptake (33). However, none of these potential actions of indomethacin could account for the ability of indomethacin to raise systemic BP or to decrease prostanoid or cAMP levels.

In summary, we have demonstrated that absence of the $\mathrm{AT}_{2}$ receptor results in increased $\mathrm{PGI}_{2}$ and $\mathrm{PGE}_{2}$ and decreased $\mathrm{PGF}_{2 \alpha}$ levels in the kidney, both basally and in response to Ang II. These findings establish a physiological role of the $\mathrm{AT}_{2}$ receptor in renal prostanoid production and metabolism. We also demonstrated that the renal vasodilator prostanoids $\mathrm{PGE}_{2}$ and $\mathrm{PGI}_{2}$ are stimulated via the $\mathrm{AT}_{1}$ receptor, pro-
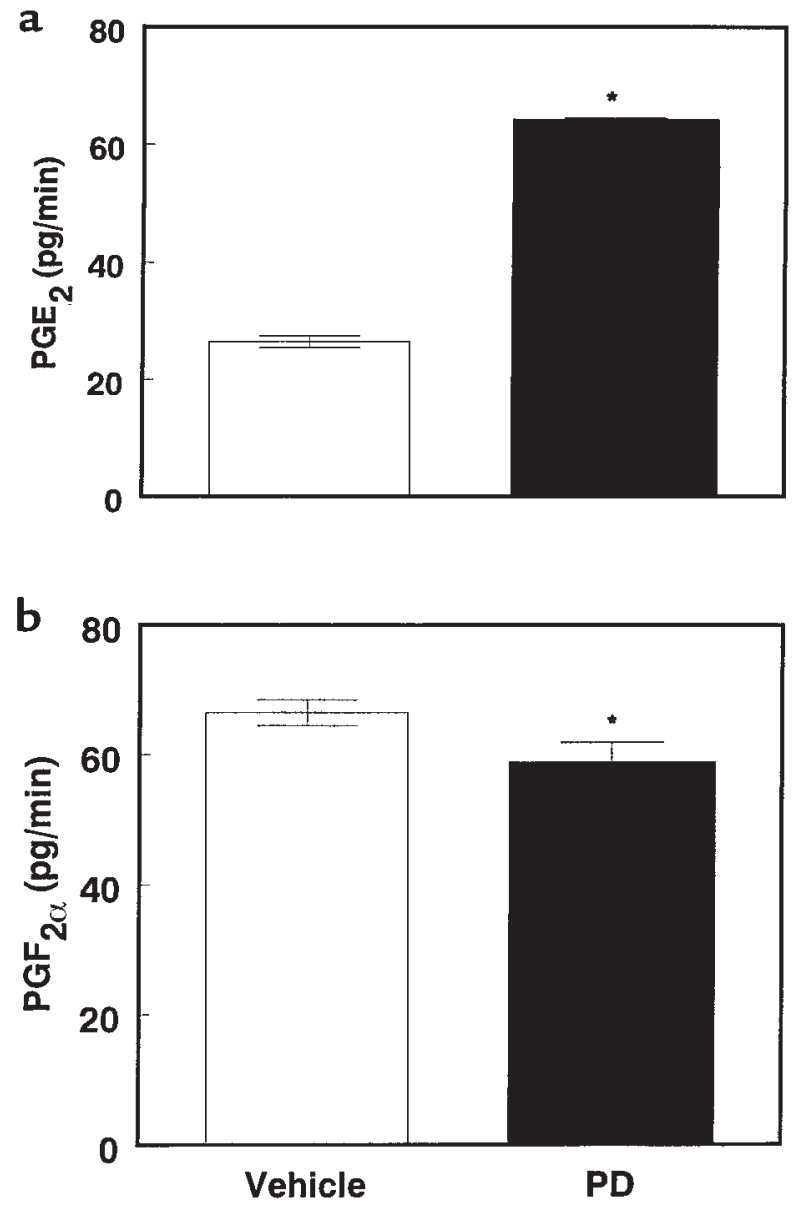

\section{Figure 6}

Incremental increase in RIF PGE $2(\mathbf{a})$ and $\mathrm{PGF}_{2 \alpha}(\mathbf{b})$ in WT mice $(n=5)$ in response to 5 days of dietary sodium restriction in the presence or absence of the $\mathrm{AT}_{2}$ receptor antagonist PD123319 (PD; $50 \mu \mathrm{g} / \mathrm{kg} / \mathrm{min}$ ). ${ }^{*} P<0.001$ vs. vehicle control.

viding counterregulatory vasodilation in opposition to the vasoconstrictor action of Ang II. Most importantly, we demonstrated that in the absence of the $\mathrm{AT}_{2}$ receptor, increased levels of these vasodilator prostanoids prevent the development of hypertension.

\section{Acknowledgments}

This work was supported by grants HL-47669 and HL57503 (to H.M. Siragy), HL-35323 and HL-58205 (to T. Inagami), and HL-49575 and HL-59948 (to R.M. Carey) from the National Institutes of Health (NIH). H.M. Siragy is the recipient of Research Career Development Award K04-HL-03006 from the NIH.

\footnotetext{
1. Goodfriend, T.L., Elliott, M.E., and Catt, K.J. 1996. Angiotensin receptors and their antagonists. N. Engl. J. Med. 334:1649-1654.

2. Matsusaka, T., and Ichikawa, I. 1997. Biological functions of angiotensin and its receptors. Annu. Rev. Physiol. 59:395-412.

3. Ozono, R., et al. 1997. Expession of the subtype-2 angiotensin $\left(\mathrm{AT}_{2}\right)$ receptor protein in the rat kidney. Hypertension. 30:1238-1246.

4. Shibata, K., et al. 1997. Upregulation of angiotensin type 2 receptor mRNA by angiotensin II in rat cortical cells. Biochem. Biophys. Res. Com-
} 
mun. 239:633-637.

5. Badr, K.F., and Jacobson, H.R. 1991. Arachidonic acid metabolites and the kidney. In The kidney. B.M. Brenner and F.C. Rector Jr., editors. W.B. Saunders. Philadelphia, PA. 584-619.

6. Siragy, H.M., and Carey, R.M. 1996. The subtype-2 (AT 2$)$ angiotensin receptor regulates renal guanosine cyclic 3', 5'-monophosphate and $\mathrm{AT}_{1}$ receptor-mediated prostaglandin $\mathrm{E}_{2}$ production. J. Clin. Invest. 97:1978-1982.

7. Siragy, H.M., and Carey, R.M. 1997. The subtype 2 angiotensin receptor regulates renal prostaglandin $\mathrm{F}_{2 \alpha}$ formation in conscious rats. Am. J. Physiol. 273:R1103-R1107.

8. Golub, M.S., Hori, M.T., and Tuck, M.L. 1996. Arachidonic acid metabolites in the vasculature. In Endocrinology of the vasculature. J.R. Sowers, editor. Humana Press. Totown, NJ. 357-371.

9. Ichiki, T., et al. 1995. Effects on blood pressure and exploratory behavior of mice lacking angiotensin II type-2 receptor. Nature. 377:748-750.

10. Siragy, H.M., and Carey, R.M. 1997. The subtype $2\left(\mathrm{AT}_{2}\right)$ angiotensin receptor mediates renal production of nitric oxide in conscious rats. $J$. Clin. Invest. 100:264-269.

11. Leung, K.H., et al. 1992. AT1 receptors mediate the release of prostaglandins in porcine smooth muscle cells and rat astrocytes. Am.J. Hypertens. 5:648-656.

12. Porsti, I., Hecker, M., Bassenge, E., and Busse, R. 1993. Dual action of angiotensin II on coronary resistance in the isolated perfused rabbit heart. Naunyn Schmiedebergs Arch. Pharmacol. 348:650-658.

13. Catalioto, R.M., Renzetti, A.R., Criscouli, M., Mizrahi, J., and Subissi, A. 1994. Angiotensins induce a release of prostacyclin from rabbit vas deferens: evidence for receptor heterogeneity. Eur. J. Pharmacol. 256:93-97.

14. Catalioto, R.M., et al. 1995. Angiotensin II-induced responses in vascular smooth muscle cells: inhibition by non-peptide receptor antagonists. Eur. J. Pharmacol. 280:285-292.

15. Cox, B.E., Rosenfeld, C.R., Kalinyak, J.E., Magness, R.R., and Shaw, P.W. 1996. Tissue specific expression of vascular smooth muscle angiotensin II receptor subtypes during ovine pregnancy. Am. J. Physiol. 271:H212-H221.

16. Muirhead, E.E., et al. 1972. Production of renomedullary prostaglandins by renomedullary interstitial cells grown in tissue culture. Circ. Res. 31(Suppl. 2):161-172.

17. Murray, M.D., and Baxter, D.C. 1993. Renal toxicity of the nonsteroid anti-inflammatory drugs. Annu. Rev. Pharmacol. Toxicol. 32:435-465.

18. McGiff, J.C., Crowshaw, K., Terragno, N.A., and Lonigro, A.J. 1970 Release of a prostaglandin-like substance into renal versus blood in response to angiotensin II. Circ. Res. 27(Suppl. 1):121-130.

19. Navar, L.G., et al. 1996. Paracrine regulation of the renal microcircula- tion. Physiol. Rev. 76:425-536

20. Bottari, S.P., deGasparo, M., Steckelings, U.M., and Levans, N.R. 1993. Angiotensin II receptor subtypes: characterization, signalling mechanisms and possible physiological implications. Front. Neuroendocrinol. 14:123-171.

21. Douglas, J.G., and Hopfer, U. 1994. Novel aspects of angiotensin receptors and signal transduction in the kidney. Annu. Rev. Physiol. 56:649-669.

22. Terragno, N.A., Malik, K.U., Nasjletti, A., Terragno, D.A., and McGiff, J.C. 1976. Renal prostaglandins. Adv. Prostaglandin Thromboxane Res. 2:561-571.

23. Weber, P.C., Larsson, C., and Scherer, B. 1977. Prostaglandin $E_{2}-9$-ketoreductase as a mediator of salt intake-related prostaglandin-renin interaction. Nature. 266:65-66.

24. Weber, P.C., et al. 1976. Stimulation of renin release from rabbit renal cortex by arachidonic acid and prostaglandin endo-peroxides. Circ. Res. 39:868-874.

25. Iino, Y., and Imai, M. 1978. Effect of prostaglandins on Na transport in isolated collecting tubules. Pflugers Arch. 373:125-132.

26. Siragy, H.M., Howell, N.L., Ragsdale, N.V., and Carey, R.M. 1995. Renal interstitial fluid angiotensin modulation by anesthesia, epinephrine, sodium depletion and renin inhibition. Hypertension. 25:1021-1024.

27. Kosonen, O., Kankaanranta, H., Malo-Ranta, U., Ristimaki, A., and Moilanen, E. 1998. Inhibition by nitric oxide-releasing compounds of prostacyclin production in human endothelial cells. Br. J. Pharmacol. 125:247-254.

28. Oyekan, A.O., and McGiff, J.C. 1998. Functional response of the rat kidney to inhibition of nitric oxide synthesis: role of cytochrome P450-derived arachidonate metabolites. Br. J. Pharmacol. 125:1065-1073.

29. Siragy, H., Jaffa, A.A., and Margolius, H.S. 1997. Bradykinin $B_{2}$ receptor modulates renal prostaglandin $\mathrm{E}_{2}$ and nitric oxide. Hypertension. 29:757-762.

30. Harder, D.R., Lange, A.R., Gebremedhin, D., Birks, E.K., and Roman, R.J. 1997. Cytochrome P450 metabolites of arachidonic acid as intracellular signalling molecules in vascular tissue. J. Vasc. Res. 34:237-243.

31. Alonso-Galicia, M., Sun, C.W., Falck, J.R., Harder, D.R., and Roman, R.J. 1998. Contribution of 20-HETE to the vasodilator actions of nitric oxide in renal arteries. Am. J. Physiol. 275:F370-F378.

32. Breyer, M.D., Jacobson, H.R., and Breyer, R.M. 1996. Functional and molecular aspects of renal prostaglandin receptors. J. Am. Soc. Nephrol. 7:8-17.

33. Parfenova, H., Hsu, P., and Leffler, C.W. 1995. Dilator prostanoidinduced cyclic AMP formation and release by cerebral microvascular smooth muscle cells: inhibition by indomethacin. J. Pharmacol. Exp. Ther. 272:44-52. 